\title{
PERFORMANCE OF TURKISH BANKING AND MEASURE OF ADDED VALUE/INPUT COSTS
}

\author{
H. Şaduman OKUMUŞ \\ İstanbul Ticaret Üniversitesi, Yardımcı Doçent Dr.
}

Özet: Bu çalışma Türk bankacıllğının performansını ölçme ve değerlendirmede "katma değer yaklaşımın”" uygulamayı amaçlamaktadtr. Geleneksel performans ölçülerine alternatif olarak "katma değer yaklaşımı" Türkiye'de faaliyette bulunan bankalara 1989-1995 dönem verileri kullantlarak uyarlanmıştur. Performans ölçüsï olarak Katma Değer / Girdi Maliyeti $(A V / I C)$ oranı çalışlan dönem için hesaplanmıştır. Söz konusu dönemde bankalarn performansinda genelde bir kötüleşme gözlemlenmiştir. Buna ilave olarak en karlı banka grubunun yabancl ticari bankalar, en az karl banka grubunun da yatırm ve kalkınma bankaları olduğu ileri sürülebilir. Ayrtca, Türk bankalanntn performasındaki kötüleşme bankalarn hissedarlarnn aldıklart risk ve yaptkklarn yattrım karşllı̆̆ında (diğer yatırım alternatifleri ile karşllaşttrmal olarak) yeterince tatmin etmekten uzak olduklarını önermektedir

\section{INTRODUCTION}

The sole use of traditional measures or combinations of them has been questioned in the literature in terms of measuring performance of firms. This stems from the fact that performance measures such as return on assets, or return on equity are only capable of illustrating certain aspects of a firm's performance and the industry in which the firm operates.

Alternative approaches have been suggested as more suitable measures of the performance of industrial and commercial firms. One such approach is called the "Added Value Approach" [1-4], which is based on the added value concept for individual firms. In Section II, "Added Value Approach", namely value-added concept, is adapted for banking industry as an alternative performance measure relative to traditional measures of performance. In the following, value-added measure by calculating the Added Value to Input Costs (AV/IC) ratio is calculated for the Turkish banks for the period 19891995. The estimates of the AV/IC values as an indicator of performance for the Turkish banks are given in Section 4 for the period studied. This is followed by some conclusions drawn from the study.

\section{ADDED VALUE CONCEPT AS A MEASURE OF PERFORMANCE}

"Added value approach" is basically a measure of the amount by which the value of corporate output exceeds the value of all the inputs used by the firm. According to this concept, the true performance of a firm is defined as the part of corporate income that remains after the deduction of the costs of the capital employed (From this perspective, although it is not a direct measure of profitability, the AV/IC ratio can be considered to be a measure of profitability, where income here is now excess income or economic rent) [3]. The capital employed by an enterprise - in the same way as its staff, for instance - is an input factor and must be remunerated in accordance with market conditions. The cost of capital must accordingly be deducted from corporate income.

The added value of a firm can be calculated using the following formula:

$$
A V=\text { Income - Opportunity cost of capital, }
$$

where

$$
\text { Income }=\text { Corporate income, }
$$

Opportunity cost of capital $=$ Capital employed $*$ Cost of capital[2]

and

Cost of capital $=$ Return on Federal bonds. 
When calculating added value, several important points require attention. The corporate income and the definition of capital chosen should coincide and the capital employed has to be evaluated at current costs. The opportunity cost of capital is associated with long-term nominal interest rate, since all other data is usually given in nominal terms and it is assumed that the capital invested in a company cannot be reinvested as rapidly as say, a money market investment. In order to compare undertakings of different sizes, the added value must be normalised in an appropriate manner. To this end, as a reference figure such as the cost of all inputs may be used. As such, specific profitability performance of individual firms at different scales, based on the "added value" concept and taking into account all of the input factors, can be measured as follows:

$$
\begin{gathered}
\text { Added Value over Input Costs } \\
(A V / I C)
\end{gathered}=\frac{\text { Added Value }}{\text { Input Costs }}
$$

where

Input Costs $=$ Staff Expenses + Opportunity Cost of Capital.

The ratio of added value over input costs is the measure of intensity of a firm's performance, with reference to the cost of one unit of output. That is, the $\mathrm{AV} / \mathrm{IC}$ ratio measures the extent to which management creates value from the sources provided by the shareholders. As such, it is often found that the AV/IC ratio and Return on Average Equity (ROAE) ratio are highly correlated [5].

Several advantages of the AV/IC ratio over other performance measurements are highlighted in the literature. Firstly, it is argued to be free from size effects and thus, it is unbiased in favour of capital intensive banks. Secondly, it is often a less volatile measure of performance when compared to others such as Return on Average Assets (ROAA). Thirdly, added value indicates the return for various stockholders in the business, such as employees, investors, customers and suppliers, over and above what could expect from using their resources elsewhere. Lastly, it provides a measure of a bank's competitive advantage, which is not affected by size, variable interest rates, or differences in regulatory regimes [2]. However, the added value concept is not without its problems. For example, in the determination of the opportunity cost of capital, failure to take into consideration of systematic and unsystematic market risks tends to attenuate the added value. Thereby, levels of added value calculated in this way may reflect both a competitive lead on the account of positive added value and also the risk specific to the business concerned. This is a common problem and it arise in connection with the ROAA and ROAE ratios as well [3].

\section{THE APPLICATION OF ADDED VALUE CONCEPT FOR MEASURING THE PERFORMANCE OF TURKISH BANKS}

Prior to 1992, the value added concept for measuring performance had never been applied to financial institutions such as banks, insurance companies or pension funds. One of the first studies involving the measurement of the value added concept for banks was carried out by Wirth (1993) [6]. In his study, the AV/IC ratio was calculated for 50 Swiss banks (cantonal, regional, big and all bank categories) for the period 19871991. The equity concept described below was used, since the use of a total assets concept in this context was deemed unsuitable (Note that the income variable used to calculate AV must be chosen according to the capital being considered. In the case that total assets is chosen as capital, the corresponding income is the sum of the net income (before tax) and interest paid. On the other hand, in the case that equity chosen as capital, the corresponding income consists exclusively of the net income before tax. For further discussion appropriate definition of added value, see $[3,7]$.

\section{Total asset concept}

Capital employed $=$ Cash + Loans to Banks and

Non-Banks + Other Assets = Balance Sheet Total

Income $=$ Interest Income + Non-Interest Income (net) - Staff Costs - Other Expenses = Net Income + Interest Expenses Staff Expenses - Other expenses

Income $=$ Net Income + Interest expenses

\section{Equity concept}

Capital employed $=($ Capital + Reserves $)$

Income $=$ Interest Income - Interest Expenses + Non-Interest Income (net) - Staff Costs - Other Expenses = Net Income

In his study, Wirth (1993) found that in each of the four years considered, there were banks with negative AV/IC ratio and others with an AV/IC ratio in excess of 80 per cent. He also pointed out that there was no substantial change in the ranking of banks according to this ratio over the period considered. Another study related to the use of the value added concept to measure profitability was conducted for 11 European retail 
banks [2]. According to this study 8 of the banks showed positive values for 1990. Another study, in which the added value of 25 banks from various EU countries was measured over the period 1987-1990, was undertaken by a London based team [8[. In this study, value added was calculated by adjusting operating income to reflect changes in reserves, and subtracting the cost of shareholders' equity (which includes a 10 per cent risk premium) from adjusted income (The value added calculated in this study was divided by factor inputs used by banks, and it appeared that of the 25 banks studied, only 5 added value by this measure, with the other banks achieving negative AV/I (added value over inputs) values). The adjustment in this manner of net income by reserve changes should be considered carefully for the case of Turkish banking. All changes in the "reserves" accounts of Turkish banks consist of retained earnings, and therefore they are already a part of net income before tax. Secondly, although "revaluation surplus" can be considered as changes in the value of investments it is debatable whether or not it should be added to net income. To see this consider the following questions: "Can revaluation surplus be considered as an output of a bank?" and "Does the revaluation surplus represent an increase in the real value of a bank?". In the case of Turkey, the notion of revaluation surplus is dominated by changes in inflation rather than in specific price. That is, it primarily preserves the value of fixed assets from depreciation due to increases in the level of inflation. Correspondingly, revaluation surplus does not appear to represent a bank output or an increase in real value. In view of these comments it is proposed to use Wirth's equity concept (as described above) in the calculation of added value for Turkish banks. Since measuring performance in terms of the ratio of $\mathrm{AV}$ to $\mathrm{IC}$ allows comparison between banks with different capital intensity levels (such as state commercial banks and private medium size commercial banks), and those with different labour intensities (such as the labour intensive state commercial banks and the less labour intensive foreign banks), this ratio is particularly informative for the comparison of individual banks, although this is not of primary concern here. In our calculation of added value for Turkish banks, the average annual interest rate on one year Treasury bills was used to compute the costs of the capital (One of the most ambiguous elements in applying value-added measures is the adjustments needed to calculate operating income and cost of capital [9]). As such, the sign of the AV/IC ratio, as calculated here, is determined by a bank's rate of earning relative to the rate of return on government bonds, which was artificially high in Turkey over the period considered owing to the high level of public sector borrowing [10]. From this perspective, the interpretation of the AV/IC results in what follows, may be open to debate. The equity used in the computation of opportunity cost was calculated by averaging share capital and reserves, in order to smooth the effects of changes in share capital on the calculation (For further detail regarding challenges in applying value-added measure see [9]). Note also, that in this study staff expenses denotes salaries and employee benefits, plus rental expenses.

The AV/IC ratios considered in this work, were calculated using financial statements, namely balance sheets and income statements of the banks, based on historical cost for the periods 1989-1995. The number of observations were ranged between 51 and 68 over the period studied (The data required was povided from Banks Association of Turkey, Banks in Turkey, various years.).

\section{ESTIMATES OF THE ADDED VALUE TO INPUT COSTS (AV/IC) VALUES FOR TURKISH BANKS}

In Table. 1 of Appendix.1, descriptive statistics of the AV/CC ratios for Turkish banking industry, as a whole and by bank group, are given for the period 1989-1995. It is observed that the AV/IC ratio followed an unstable trend over this period. This may be attributed to variable opportunity cost of capital on the account of changing interest rates on government bonds over the period considered. In terms of absolute values, the AV/IC ratio plummeted in 1994 with respect to previous year in each bank group except that of foreign banks. This corresponds to the decline in added value of the whole banking industry with respect to GDP. The median AV/IC performance of the industry as a whole was -9.74 per cent on average over the period considered. This should be seen as an indicator of the amount by which banks should seek to improve their performance relative to other avenues for investment. State commercial banks operated at relatively poor AV/IC levels, with a median performance of -20.69 per cent on average. In view of the fact that typically state commercial banks have high staff expenses due to over employment [11], poor performance at this level suggests that the these bank are a long way from being able to adequately compensate their shareholders (primarily the state) for the risk and sacrifice of their investment relative to other investment opportunities. On the whole, development and investment banks, with an average median AV/IC performance of : 35.86 per cent, demonstrated the poorest performance. On the other hand, foreign banks performed best with a median of 13.26 per cent on average over the period studied, reflecting an addition in value to each unit of input they use. They were followed by private national commercial banks, with average median performance of 7 per cent.

Figure.1 of Appendix.2 illustrates the cumulative frequency distribution of banks in Turkey according to the 
$\mathrm{AV} / \mathrm{IC}$ ratio for the given period. Over this period, there is a general shift to the left of the cumulative frequency functions suggesting an overall deterioration in the performance of banks as measured by the AV/IC. It is important to note that the percentage of banks with negative AV/IC ratio never fell below 45 per cent, rising to as high as 67 per cent in 1994 (clearly reflecting the financial crisis in this year). In 1995 the percentage of banks operating at an $\mathrm{AV} / \mathrm{IC}$ ratio greater than 25 per cent was the same as that in 1989 , at approximately 30 per cent. However, in this year there were significantly more banks with negative AV/IC ratio (58 per cent of all banks) compared to 1989 (45 per cent of all banks). See also the box-plots in Figures. 2 and 3 of Appendix.2.

For completeness, individual AV/IC ratios for Turkish banks and their ranking according to this are given in Table. 2 of Appendix.1. The changes in bank ranking according to the $\mathrm{AV} / \mathrm{IC}$ ratio is examined by considering Spearman's rank correlation for the period 1989-1995. The relevant figures are presented in Table. 3 of Appendix.1. The Spearman correlation coefficients suggest that : $(i)$ the ranking in 1995 was significantly different from that in 1989 , with a correlation coefficient of 0.4695 ; (ii) the level volatility of bank ranking according to the AV/IC ratio remained reasonably constant over the period 1989-1993; and finally, (iii) the largest change in bank ranking in terms of the AV/IC ratio again occurred between 1993 and 1994.

\section{CONCLUSIONS}

In this work, attention has been focused on measuring and assessing the performance of banks operating in Turkey, for the period 1989-1995. Not so commonly used measure of added value to input costs (AV/IC) was considered as an alternative indicator of performance. follows:

The outcomes of the analysis can be summarised as

The median AV/LC performance varied between -40.95 per cent in 1994 and 6.01 per cent in 1989 , with an average of -9.74 per cent over the period. It appears that on average there was an overall deterioration in the performance of the Turkish banks as measured by the AV/IC ratio over the period studied. No stable trend was observed over the period considered.

Based on the given performance measure considered, the most profitable bank group was foreign commercial banks and the least profitable, development and investment banks for the period studied.
Poor performance of the Turkish banks on average also suggests that they are a long way away from being able to adequately compensate their shareholders (primarily the state) for the risk and sacrifice of their investment relative to other investment opportunities.

\section{REFERENCES}

[1] DAVIS, E.; KAY, J., "Assessing corporate performance", Business Strategy Review, Centre for Business Strategy, Vol. 1, No: 2, Summer 1990, pp.1-16.

[2] KAY, J., Foundations of Corporate Success, Oxford University Press, 1995, pp.197-204.

[3] DAVIS, E.; FLANDERS, S.; STAR, J., "Who are the world's most successful companies?", Business Strategy Review, Vol. 2, No: 2, Summer 1991, pp.23-30.

[4] DAVIS, E.; STAR, J., "The world's best performing companies", Business Strategy Review, Vol. 4, No: 2, Summer 1993, pp.1-17.

[5] SPREMANN, K., "Comments on measuring the performance of banks: conceptual problems and results for Switzerland (1987-199I)", in N. Blattner, H. Genberg and A. Swoboda (eds.), Banking in Switzerland, Heildberg: Physica-Verlag, 1993.

[6] WIRTH, M., "Measuring the performance of banks: conceptual problems and results for Switzerland (19871991), in N. Blatter, H. Genberg and A. Swoboda (eds.); Banking in Switzerland, Heildberg: Physica-Verlag, 1993.

[7] GRILICHES, Z., "Output Measurement in the Service Sector", National Bureau of Economic Research, Vol. $56,1992$.

[8] DAVIS, E.; GOUZOULI, C.; SPENCE, M.; STAR, J., "Measuring the performance of banks", Business Strategies Review, Centre for Business Strategy, Vol. 4; No: 3, Autumn 1993.

[9] PETERSON, P.P.; PETERSON, D.R., Company Performance and Measures of Value-Added, The research Foundation of the Institute of Chartered Financial Analysts, 1996, pp.24-26.

[10] OKUMUS, H.S., "Profitability Analysis of the Turkish Banking Within The Context of the European Single Market for Financial Services", Unpublished PhD Thesis, Anglia Polytechnique University, Ashcroft International Business School, 1999.

[11] ALTUNBAS, Y;; SARISU, A., [in Turkish] Integration of the Turkish Banking System to the European Banking, The Undersecretariat of Treasury, Economic Research Department, Ankara, 1996, pp.51-52. 
Appendix.1 AV/IC Ratios -Descriptive Statistics

Table.1: Descriptive Statistics of the AV/IC Ratios (as a percentage)

\begin{tabular}{|c|c|c|c|c|c|c|c|}
\hline & 1989 & 1990 & 1991 & 1992 & 1993 & 1994 & 1995 \\
\hline \multicolumn{8}{|l|}{ All Banks } \\
\hline Quartile 1 & -26.05 & -18.67 & -30.48 & -19.71 & -34.86 & -79.43 & -49.88 \\
\hline Quartile 2 & 6.01 & 1.45 & -7.36 & -2.08 & -5.05 & -40.95 & -20.25 \\
\hline Quartie 3 & 39.00 & 20.12 & 25.27 & 7.88 & 24.51 & 10.07 & 42.28 \\
\hline Mean & -9.25 & -0.68 & -6.07 & -3.96 & -1.46 & -29.79 & -7.33 \\
\hline Std. Dev. & 54.35 & 48.90 & 51.89 & 33.37 & 50.64 & 104.70 & 89.77 \\
\hline $\operatorname{Max}$ & 138.25 & 106.66 & 125.94 & 110.67 & 178.26 & 346.71 & 306.68 \\
\hline Min & -143.21 & -133.31 & -156.89 & -116.85 & -81.47 & -418.40 & -425.16 \\
\hline No. Banks & 51 & 55 & 59 & 66 & 67 & 67 & 68 \\
\hline \multicolumn{8}{|l|}{ All Commercial } \\
\hline Quartile 1 & -15.74 & -9.57 & -28.95 & -16.68 & -31.29 & -67.68 & -41.2 \\
\hline Quartile 2 & 10.8 & 7.78 & -1.28 & -0.23 & -2.78 & -37.29 & -12.98 \\
\hline Quartile 3 & 39.99 & 24.91 & 26.51 & 12.09 & 24.51 & 14.46 & 46.78 \\
\hline Mean & 74.84 & 3.69 & -3.72 & -1.09 & 2.07 & -20.92 & -5.2 \\
\hline Std. Dev. & 55.11 & 47.92 & 51.5 & 35.31 & 50.04 & 107.4 & 85.74 \\
\hline $\operatorname{Max}$ & 138.25 & 106.66 & 114.75 & 110.67 & 178.26 & 346.71 & 204.86 \\
\hline Min & -143.21 & -133.31 & -156.89 & -116.68 & -75.44 & -418.4 & -425.16 \\
\hline No. Banks & 42 & 45 & 49 & 54 & 55 & 55 & 55 \\
\hline \multicolumn{8}{|l|}{ Private National Com. } \\
\hline Quartile 1 & -14.90 & -7.21 & -16.28 & -19.50 & -33.40 & -72.91 & -47.99 \\
\hline Quartile 2 & 1.16 & 9.88 & 0.40 & -0.94 & -1.31 & -45.29 & -14.72 \\
\hline Quartie 3 & 35.86 & 24.58 & 26.71 & 7.92 & 35.85 & -3.87 & 39.33 \\
\hline Mean & 6.57 & 8.24 & 4.51 & 0.91 & 8.67 & -37.22 & -0.65 \\
\hline Std. Dev, & 48.59 & 42.20 & 46.98 & 30.85 & 54.15 & 48.00 & 60.91 \\
\hline $\operatorname{Max}$ & 131.24 & $106.6 \overline{6}$ & 914.75 & 94.49 & 178.26 & 66.71 & 204.86 \\
\hline Min & -91.72 & -89.64 & -103.28 & -44.86 & -75.44 & -146.61 & -76.83 \\
\hline No. Banks & 23 & 24 & 26 & 31 & 32 & 32 & 32 \\
\hline \multicolumn{8}{|l|}{ Foreign } \\
\hline Quartile 1 & 0.95 & -13.51 & -41.5 & -13.07 & -30.78 & -57.64 & -38.8 \\
\hline Quartile 2 & 36.79 & -0.31 & 7.64 & 2.01 & -5.02 & 17.63 & 34.08 \\
\hline Quartile 3 & 78.54 & 31.59 & 28.84 & 15.58 & 13.8 & 145.04 & 76.72 \\
\hline Mean & 33.87 & 1.00 & -2.02 & 1.56 & -2.39 & 34.81 & 74.92 \\
\hline Std. Dev. & 69.44 & 57.17 & 47.59 & 36.74 & 45.31 & 138.8 & 74.37 \\
\hline Max & 138.25 & 93.34 & 77.71 & 110.67 & 133.66 & 346.71 & 115.68 \\
\hline Min & -143.21 & -133.31 & -102.24 & -69.73 & -69.77 & -198.35 & -180.63 \\
\hline No. Banks & 14 & 16 & 18 & 18 & 18 & 18 & 18 \\
\hline \multicolumn{8}{|l|}{ State Com. } \\
\hline Quartile 1 & -24.59 & -51.54 & -122.83 & -64.25 & -52.75 & -241.31 & -236.48 \\
\hline Quartile 2 & 6.01 & -9.98 & -24.10 & -11.61 & -18.08 & -48.39 & -38.73 \\
\hline Quartie 3 & 20.53 & 32.75 & 3.07 & 12.34 & 1.57 & -27.77 & -11.02 \\
\hline Mean & -0.41 & -9.51 & -52.72 & -23.08 & -24.09 & -117.31 & -106.75 \\
\hline Mean (exc. Etibank) & -6.24 & 9.21 & -26.68 & 0.35 & -11.47 & -42.04 & -27.15 \\
\hline Std. Dev. & 22.92 & 48.95 & 70.43 & 54.53 & 32.58 & 169.14 & 179.21 \\
\hline Max & 22.86 & 45.39 & 21.04 & $25 . \overline{21}$ & 13.72 & -18.24 & 7.22 \\
\hline Min & -25.65 & -84.41 & -156.89 & -116.85 & -74.60 & -418.40 & -425.16 \\
\hline No. Banks & 5 & 5 & 5 & 5 & 5 & 5 & 5 \\
\hline \multicolumn{8}{|l|}{ Dev. and lnv. } \\
\hline Quartile 1 & -45.73 & -55.81 & .5 .6 & -36.35 & -62.67 & -98.99 & -75.95 \\
\hline Quartile 2 & -40.29 & -18.68 & -22.98 & -12.12 & -28.95 & -84.82 & -43.21 \\
\hline Quartile 3 & 79.12 & -1.85 & -10.82 & -0.71 & 26.76 & -43.46 & 2.19 \\
\hline Mean & -16.8 & -20.4 & -17.59 & -16.87 & $-17.69^{\circ}$ & -70.44 & -.76 .35 \\
\hline Std. Dev. & 44.38 & 50.92 & 54.99 & 18.76 & 52.39 & 84.43 & 108.62 \\
\hline Max & 69.73 & 94.01 & 125.94 & 8.39 & 71.05 & 89.05 & $3 \overline{06.68}$ \\
\hline $\operatorname{Min}$ & -53.70 & .85 .14 & -73.55 & -42.25 & -81.47 & -247.29 & .175 .77 \\
\hline No. Banks & 9 & $\overline{10}$ & 10 & 12 & $\overline{12}$ & 12 & 13 \\
\hline
\end{tabular}


Table.2: The AV/IC Ratios for Turkish Banks (as a percentage)

\begin{tabular}{|c|c|c|c|c|c|c|c|c|c|c|c|c|c|c|c|}
\hline & & & & & & & & & & & & & & & \\
\hline Type & Banks & 1989 & 1990 & 1991 & 1992 & 1993 & 1994 & 1995 & 1989 & 1990 & 1991 & 1992 & 1993 & 1994 & 1995 \\
\hline 1 & $A B N$ & 11,01 & $-3,99$ & 5,26 & $-14,80$ & $-7,22$ & 39,98 & 33,37 & 23 & 33 & 24 & 45 & 36 & 12 & 21 \\
\hline 0 & Adabank & $-44,43$ & 48,79 & 39,20 & -19.59 & $-38,09$ & $-79,44$ & $-68,62$ & 44 & 7 & 8 & 50 & 53 & 51 & 59 \\
\hline 0 & Akbank & 22,67 & 28,30 & 25,28 & 2,03 & 22,32 & 7,81 & 61,69 & 19 & 11 & 15 & 24 & 18 & 19 & 12 \\
\hline 0 & Alternatif bank & n.a. & n.a. & n.a. & 15,72 & 30,05 & $-40,91$ & 12,84 & . & . & . & 10 & 14 & 33 & 27 \\
\hline 1 & Arapturk & $-143,21$ & $-133,32$ & $-70,47$ & $-38,29$ & $-49,01$ & $-52,21$ & $-34,57$ & 51 & 55 & 53 & 59 & 56 & 38 & 43 \\
\hline 1 & Banca di Rom & 7,36 & $-1,56$ & 16,78 & 3,06 & $-53,59$ & $-158,86$ & $-180,64$ & 25 & 32 & 18 & 21 & 58 & 64 & 67 \\
\hline 0 & Bank Kapital & n.a. & n.a. & $-103,28$ & $-19,51$ & $-31,29$ & $-146,61$ & $-59,43$ & . & & 58 & 49 & 48 & 63 & 55 \\
\hline 2 & Bilesik Yatirim & $-40,98$ & $-4,41$ & $-11,01$ & $-4,18$ & $-33,59$ & $-83,58$ & $-115,78$ & 43 & 36 & 34 & 36 & 49 & 55 & 66 \\
\hline 0 & Bilesik Korfez & 91,38 & 93,35 & 114,75 & 94,50 & 178,26 & 46,14 & 204,86 & 5 & 4 & 2 & 2 & 1 & 11 & 2 \\
\hline 1 & Bank Mellat & 101,35 & 73,45 & $-11,57$ & $-2,45$ & $-28,75$ & 25,20 & 56,80 & 4 & 5 & 35 & 34 & 46 & 15 & 14 \\
\hline 1 & $B N P$ & 104,11 & 19,05 & 33,23 & 0.04 & $-21,25$ & 8.56 & 84,69 & 3 & 15 & 9 & 29 & 43 & 18 & 5 \\
\hline 1 & Chemical & n.a. & n.a. & 10,03 & 13,48 & 50,02 & 139,76 & 115,69 & & $\ldots$ & 22 & 12 & 9 & 5 & 3 \\
\hline 1 & Citibank & 25,68 & $-0,31$ & 39,95 & 25,53 & 11,26 & 170,58 & 34,80 & 17 & 29 & 7 & 6 & 24 & 3 & 20 \\
\hline 1 & Credit Lyonna & 34,58 & $-1,51$ & 23,49 & 4,43 & 0,11 & $-113,56$ & $-53,62$ & 16 & 31 & 16 & 19 & 27 & 61 & 53 \\
\hline 0 & Demirbank & $-2,30$ & 12,32 & $-2,23$ & 2,21 & 69,92 & $-6,28$ & 97,23 & 30 & 21 & 27 & 23 & 6 & 24 & 4 \\
\hline 0 & Derbank & n.a. & $-56,53$ & $-27,42$ & $-41,33$ & $-72,37$ & $-81,18$ & $-71,89$ & & 49 & 43 & 61 & 64 & 52 & 60 \\
\hline 0 & Egebank & $-35,95$ & $-47,57$ & $-9,91$ & 7,93 & $-0,65$ & $-66,01$ & $-30,01$ & 41 & 45 & 31 & 16 & 29 & 45 & 40 \\
\hline 2 & Ege Glyim San & n.a. & n.a. & n.a. & n.a. & n.a. & n.a. & $-57,19$ & $\therefore$ & . & $\therefore$ & . &. & . & 54 \\
\hline 0 & Ekspress & n.a. & n.a. & n.a. & 28,13 & 42,34 & $-74,66$ & $-20,27$ & . & . & . & 5 & 11 & 49 & 35 \\
\hline 3 & T. Emak & $-23,52$ & $-9,99$ & $-88,77$ & $-11,61$ & $-18,09$ & $-48,40$ & $-47,80$ & 37 & 40 & 56 & 41 & 40 & 35 & 51 \\
\hline "' & Eskisehir banke & 5,96 & 2,96 & $-35,93$ & $-24,00$ & $-39,66$ & $-81,30$ & $-62,57$ & 27 & 26 & 46 & 54 & 54 & 53 & 56 \\
\hline 3 & Etibank & 22,87 & $-84,41$ & $-156,89$ & $-116,86$ & $-74,60$ & $-418,41$ & $-425,16$ & 18 & 51 & 59 & 66 & 65 & 67 & 68 \\
\hline 0 & Finansbank & 131,24 & 106,66 & 62,76 & 41,67 & 93,51 & 2,03 & 51,61 & 2 & 1 & 5 & 4 & 4 & 22 & 15 \\
\hline 0 & Garanti Bankas & $-5,81$ & 7.78 & 9.95 & 15,66 & 37.79 & 6,37 & 16,03 & 32 & 24 & 23 & 11 & 12 & 20 & 26 \\
\hline 0 & Garanti Y atirim & n.a. & n.a. & n.a. & 91,60 & 106,75 & $-65,51$ & 35,55 & & . & . & 3 & 3 & 43 & 19 \\
\hline 1 & Habibbank & 39,01 & 23,13 & $-30,49$ & $-43,83$ & $-69,77$ & $-73,96$ & $-41,49$ & 13 & 13 & 45 & 63 & 63 & 48 & 49 \\
\hline 3 & T. Halkbank & $-25,66$ & $-18,67$ & $-14,91$ & $-11,66$ & $-30,92$ & $-37,30$ & $-38,74$ & 38 & 42 & 37 & 42 & 47 & 30 & 46 \\
\hline 0 & Iktisat Bankasi & 35,86 & $-9,16$ & 16,62 & 1,86 & 6,42 & $-49,68$ & $-25,09$ & 15 & 39 & 19 & 25 & 25 & 36 & 38 \\
\hline 2 & Uler Bankasi & $-53,70$ & $-49,58$ & $-48,58$ & $-37,83$ & $-53,37$ & $-56,40$ & $-16,56$ & 48 & 47 & 50 & 58 & 57 & 39 & 33 \\
\hline 0 & Imar Bankasi & $-59,36$ & $-4,16$ & 28,50 & $-5,17$ & $-48,08$ & $-83,10$ & $-76,83$ & 49 & 35 & 11 & 37 & 55 & 54 & 63 \\
\hline 2 & Indosuez Eurs & n.a. & $-85,14$ & $-28,87$ & $-20,08$ & $-24,32$ & $-99,60$ & $-109,84$ & 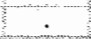 & 52 & 44 & 51 & 45 & 59 & 65 \\
\hline 0 & Interbank & 55,29 & 41,43 & 12,27 & 7,87 & -21.61 & $-67,69$ & $-63,24$ & 10 & 9 & 21 & 17 & 44 & 47 & 57 \\
\hline 0 & Isbankasi & 10,60 & 1,46 & -4.83 & $-0,94$ & 17,82 & 14,46 & 27,34 & 24 & 28 & 29 & 32 & 19 & 16 & 22 \\
\hline 0 & Kentbank & n.a. & n.a. & n.a. & $-20,18$ & 12,17 & $-61,60$ & $-20,23$ & $\therefore$ & $\therefore$ & . & 52 & 23 & 41 & 34 \\
\hline 1 & Kibris Kredi & $-26,06$ & $-53,39$ & $-42,67$ & $-12,50$ & $-11,78$ & 10,07 & $-41,21$ & 39 & 48 & 48 & 44 & 38 & 17 & 48 \\
\hline 0 & Kocbank & 13,84 & 13,26 & 31,35 & $-6,65$ & $-1,98$ & $-9,14$ & 40,60 & 22 & 20 & 10 & 38 & 30 & 25 & 18 \\
\hline 1 & Midland & n.a. & $-90,42$ & $-59,46$ & 12,94 & 13,23 & 46,90 & 74,64 & $\therefore$ & 54 & 51 & 13 & 22 & 10 & 9 \\
\hline 0 & Miili Aydin & $-4,83$ & 17,37 & $-3,51$ & $-30,12$ & $-18,64$ & $-113,07$ & $-7,14$ & 31 & 17 & 28 & 55 & 42 & 60 & 29 \\
\hline 1 & Osmanli Bank & 60,48 & 34,42 & 62,19 & 110,68 & $-0,38$ & 160,90 & 65,88 & 9 & 10 & 6 & 1 & 28 & 4 & 11 \\
\hline 0 & Pamukbank & $-53,69$ & $-42,22$ & $-43,57$ & $-16,00$ & $-34,87$ & $-51,66$ & $-37,27$ & 47 & 44 & 49 & 47 & 51 & 37 & 44 \\
\hline 2 & Park Yatirim & n.a. & n.a. & n.a. & $-42,26$ & 67,43 & $-86,06$ & $-73,42$ & . & . & 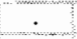 & 62 & 7 & 56 & 61 \\
\hline 1 & Saudi America & 70,94 & 57,63 & 77,72 & 0,96 & 29,78 & 92,20 & $-38,00$ & 6 & 6 & 4 & 27 & 15 & 6 & 45 \\
\hline 0 & Sekerbank & 1,16 & 11,29 & $-10,36$ & $-15,75$ & 24,52 & $-24,61$ & $-40,24$ & 28 & 22 & 33 & 46 & 17 & 28 & 47 \\
\hline 2 & Sinai Yatirim $\mathbf{k}$ & 69,73 & 4,57 & $-10,29$ & $-1,71$ & 1,23 & 48,42 & 58,34 & 7 & 25 & 32 & 33 & 26 & 9 & 13 \\
\hline 1 & Socite Genera & n.a. & 15,66 & 27,38 & 3,96 & $-2,83$ & 229,59 & 74,46 & 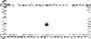 & 18 & 12 & 20 & 33 & 2 & 10 \\
\hline 0 & Sumerbank & $-91,72$ & $-89,65$ & $-85,05$ & $-44,86$ & $-75,45$ & 4,48 & $-50,58$ & 50 & 53 & 55 & 64 & 66 & 21 & 52 \\
\hline 2 & Tat Yatirim & n.a. & n.a. & n.a. & $-31,83$ & $-81,47$ & $-91,64$ & $-78,48$ & . & & 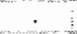 & 56 & 67 & 57 & 64 \\
\hline 3 & T.C Ziraat Bank & 6,02 & 45,39 & 21,05 & 25,21 & 13,73 & $-64,23$ & $-29,28$ & 26 & 8 & 17 & 7 & 21 & 42 & 39 \\
\hline 0 & T.D is Ticaret & $-6,34$ & 14,18 & $-7,37$ & 11,81 & 65,59 & $-57,22$ & 46,78 & 34 & 19 & 30 & 14 & 8 & 40 & 16 \\
\hline 2 & T.Ihracat Kred & $-5,99$ & $-74,51$ & $-73,55$ & $-31,91$ & $-61,00$ & $-65,56$ & $-43,22$ & 33 & 50 & 54 & 57 & 60 & 44 & 50 \\
\hline 2 & T.Kalkinma & $-44,70$ & $-32,53$ & $-64,71$ & $-39,20$ & $-63,24$ & $-247,30$ & $-64,83$ & 45 & 43 & 52 & 60 & 61 & 66 & 58 \\
\hline 2 & T.Sinai Kalkin & $-32,79$ & $-4,83$ & $-18,89$ & $-3,05$ & 35,28 & $-39,15$ & 17,34 & 40 & 37 & 38 & 35 & 13 & 32 & 25 \\
\hline 3 & T.Vakiflar Bank & 18,21 & 20.12 & $-24,10$ & $-0,52$ & -10.59 & $-18,25$ & 7,23 & 21 & 14 & 41 & 31 & 37 & 27 & 28 \\
\hline 2 & Tekfen Yatirim & $-46,77$ & $-4,00$ & $-26,34$ & $-0,39$ & $-64,44$ & $-97,20$ & -22.65 & 46 & 34 & 42 & 30 & 62 & 58 & 37 \\
\hline 0 & Tekstil & 42,96 & 18,28 & $-20,90$ & $-20,57$ & 24,68 & 26,18 & 19,77 & 12 & 16 & 40 & 53 & 16 & 13 & 23 \\
\hline 1 & The Chase Mai & 138,26 & 94,35 & 26,91 & 21,89 & 133,67 & 346,72 & 83,12 & 1 & 2 & 13 & 9 & 2 & 1 & 6 \\
\hline 0 & Toprakbank & n.a. & n.a. & n.a. & $-18,72$ & $-2,26$ & $-67,30$ & 17,67 & & $\therefore$ & . & 48 & 31 & 46 & 24 \\
\hline 0 & Turk Boston & n.a. & n.a. & 102,04 & 6,37 & $-54,77$ & 25,67 & $-9,21$ & $\cdot$ & . & 3 & 18 & 59 & 14 & 30 \\
\hline 0 & Turk Ekonomi & 38.98 & $-8,24$ & 14,57 & 2.96 & 45,42 & 66,71 & 42.85 & 14 & 38 & 20 & 22 & 10 & 8 & 17 \\
\hline 2 & Turk Merchant & 44,24 & 94,01 & 125,95 & 8,39 & 71,06 & 89,05 & 306,68 & 11 & 3 & 1 & 15 & 5 & 7 & 1 \\
\hline 1 & Turk Sakura & $-18,26$ & -16.75 & $-41,12$ & $-69,74$ & $-36,89$ & $-5,91$ & 81,78 & 36 & 41 & 47 & 65 & 52 & 23 & 7 \\
\hline 0 & Turk Ticarel & 0.94 & 2.75 & $-14,75$ & $-12,21$ & $-18,23$ & $-29,45$ & $-20,57$ & 29 & 27 & 36 & 43 & 41 & 29 & 36 \\
\hline 1 & Turkish Bank & n.a. & n.a. & $-102,25$ & $=9,58$ & $-15,23$ & $-40,96$ & $-12,99$ & . & & 57 & 40 & 39 & 34 & 32 \\
\hline 0 & Tutunbank & $-14,90$ & 8,48 & 26,12 & 0.95 & $-2,79$ & $-38,37$ & $-31,86$ & 35 & 23 & 14 & 28 & 32 & 31 & 41 \\
\hline 1 & Westdeutche & 69,01 & $-0,32$ & $-1,28$ & 22,34 & 15,52 & $-198,35$ & $-34,12$ & 8 & 30 & 26 & 8 & 20 & 65 & 42 \\
\hline 0 & Yapi Kredi & 19,69 & 26,69 & 3,04 & $-7,20$ & $-5,06$ & $-17,22$ & 75,81 & 20 & 12 & 25 & 39 & 34 & 26 & 8 \\
\hline 2 & Yatirim Ban k & $-40,30$ & $-47,66$ & $-19,64$ & 1,55 & $-5,94$ & $-116,32$ & $-12,95$ & 42 & 46 & 39 & 26 & 35 & 62 & 31 \\
\hline 0 & Yurtbank & n.a. & n.a. & n.a. & n.a. & $-34,11$ & $-79,03$ & $-76,62$ & . & . & . & . & 50 & 50 & 62 \\
\hline
\end{tabular}

Note: " 0 " denotes private national commercial banks, " 1 " foreign commercial banks, " 2 " development and investment banks, and "3" state commercial banks. 
Table.3: Spearman Correlation Coefficients - AV/IC

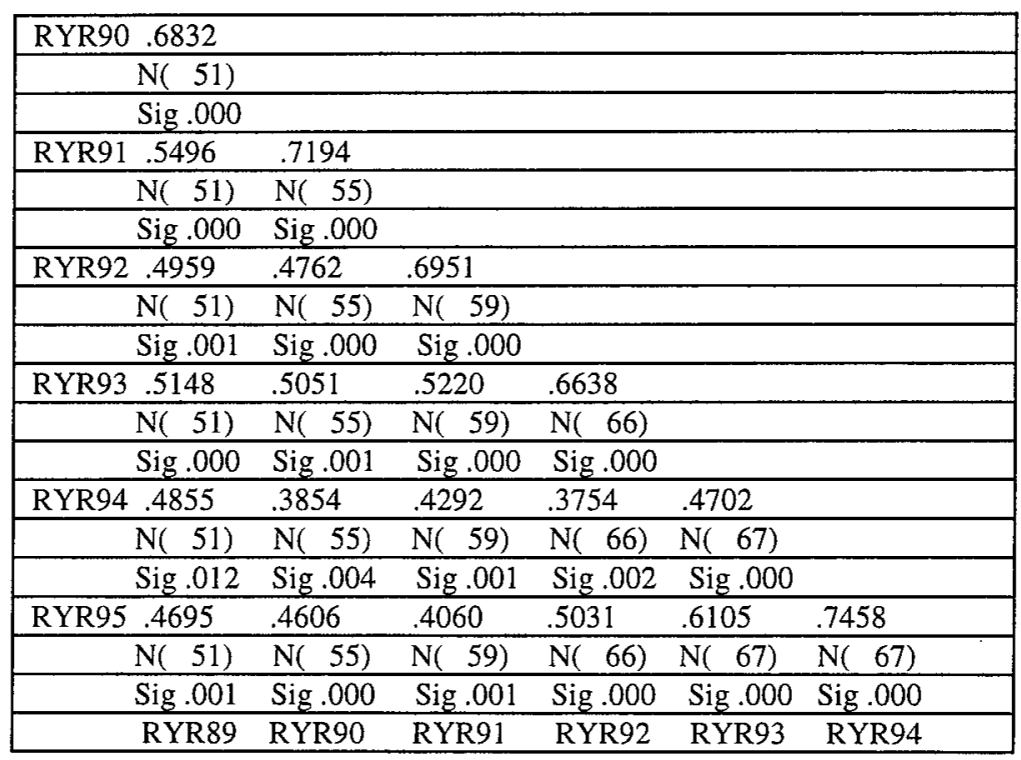




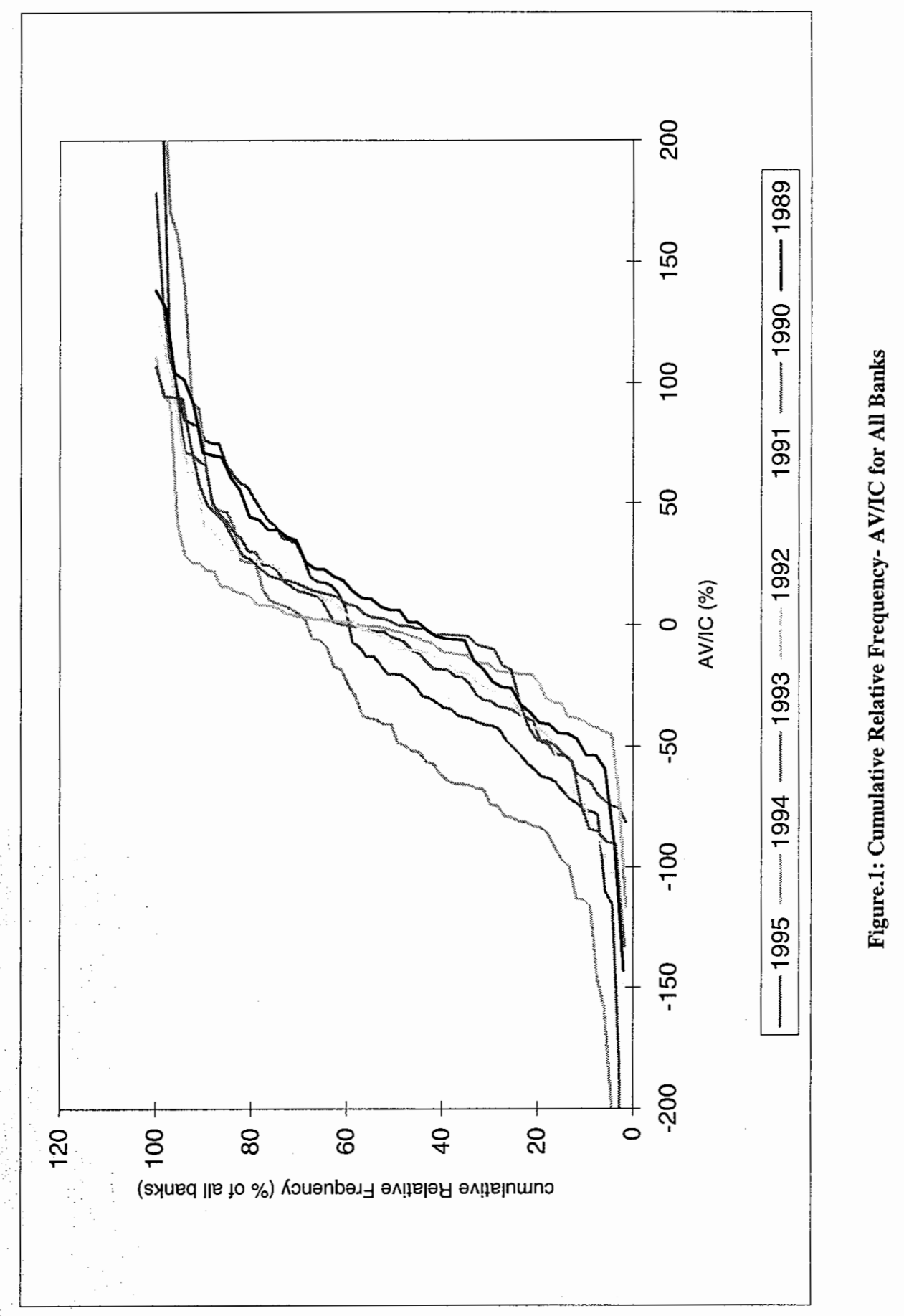


Appendix.2 Cumulative Relative Frequency and Boxplots for the AV/IC Ratio

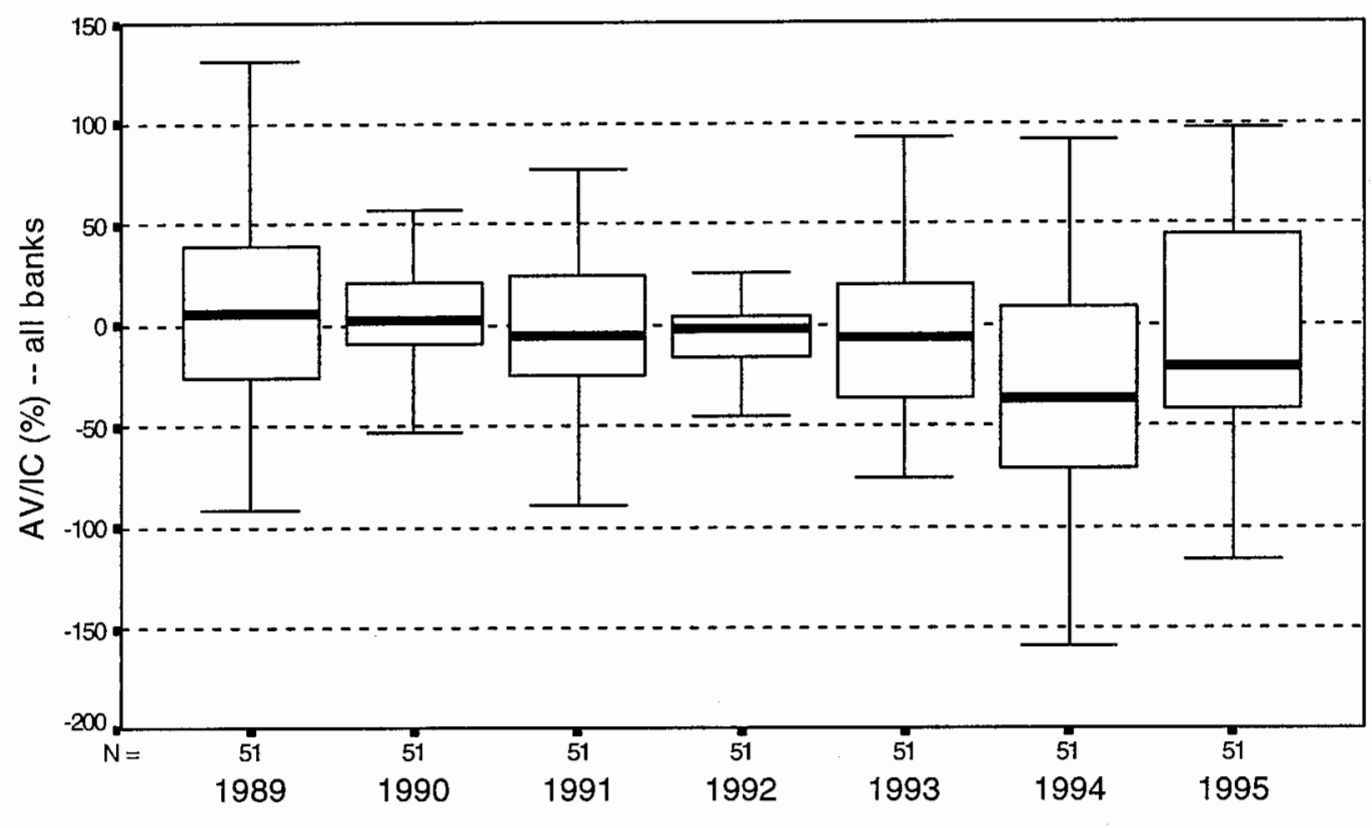

Figure.2: AV/IC Ratio Boxplots - All Banks

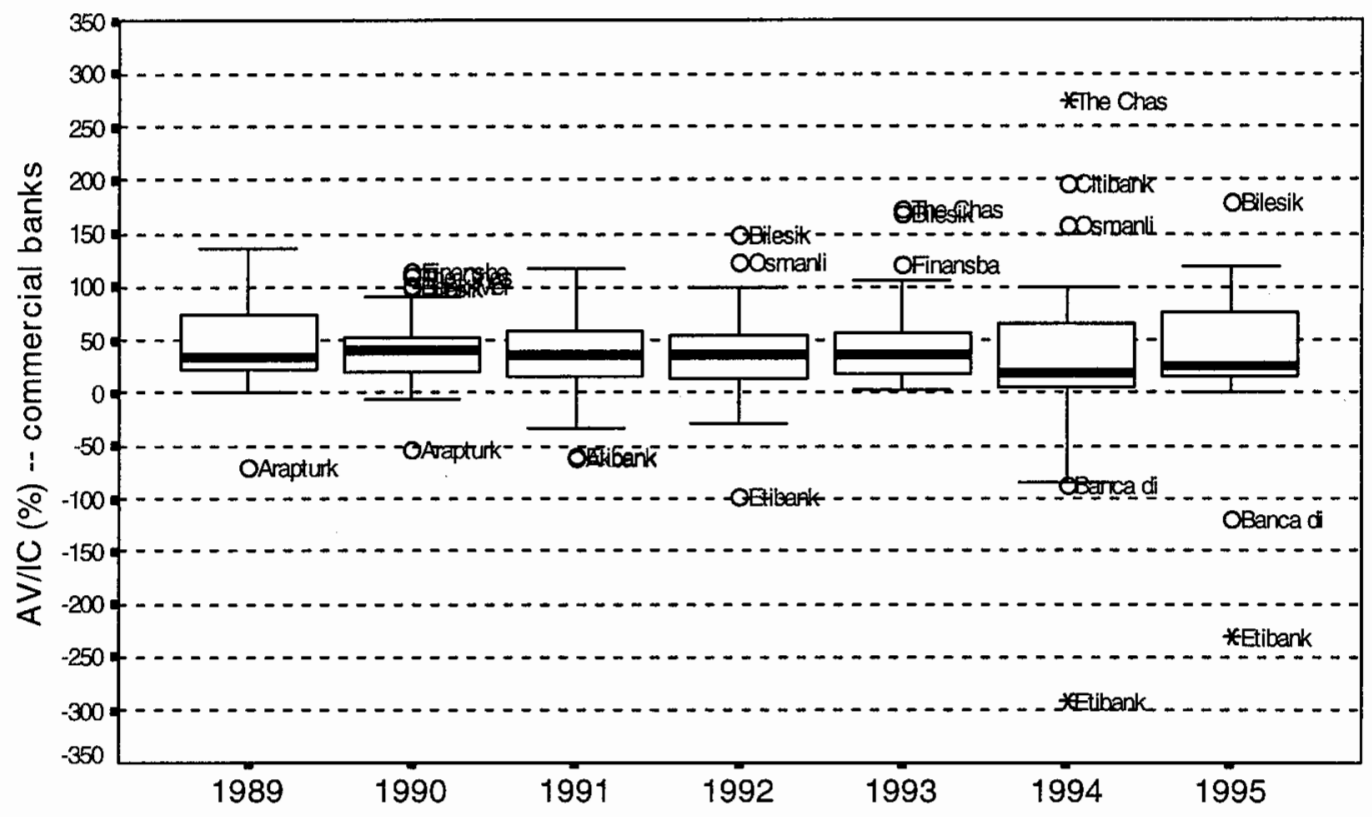

Figure.3: AV/IC Ratio Boxplots - Commercial Banks 
